\title{
GERAKAN KOMUNITAS CANGKIR KAMISAN MEMBANGUN EKONOMI KREATIF DI METRO LAMPUNG
}

\author{
Oleh: \\ Dharma Setyawan, MA \\ dharmasetyawan@rocketmail.com \\ STAIN Jurai Siwo Metro Lampung
}

\begin{abstract}
This Research reveals the role of the Community Cup Kamisan. A community that started its operations from discussions talk think (cups) in the core of the house of the host. Anxiety the pegiatnya consisting of academics, activists, journalists, citizen, teachers, businessmen, were enterprising, and various creative community city. Kamisan Cup community is attempting to revive the role of the various entities in the City Metro Lampung with spirit to build the collective intellectual property. Lampung province which is known with various ethnic conflict, through collective intellectual movement is starting to realize the importance of building togetherness. Borrowed the term Arnold J. Toynbe namely build "creative minority" namely Cups Kamisan community efforts to build the city with the empowerment of various community entities.

Kamisan Cup community is a multicultural community who are also trying to develop a creative economy. Consists of various backgrounds from academics, Student activists, journalists, creative citizens, religious leaders unite the idea of building a social movement. Many changes occur from build Citizen journalism portal pojoksamber. com, House Together, research institution Sai Wawai Institute, publication of indie Sai Wawai Publishing, and establish Waste Bank Green cups. In addition many movements of other creative economy that is done by this community. E.g. with began to build the other creative economy documentary, music, and handicrafts.

Intellectual Property and the community experienced a because it is based on the logic of politics and keilmuwan at the time of the formation of the term intellectual property. "intellectuals" born from social classes who do claim against the injustice done by the state. The state since the formation, have special characters in the form of domination. In the second phase of the state that is free, that domination continues to the community. In this case, researchers intend to explore the role of the Community Cup Kamisan answer the challenge in
\end{abstract}


building the structure of the output of the community and are able to progress and work for the community. The collective intellectual discourse interesting to examined as part of the responsibility of universities build changes through the way intellectualism naturally dissipate namely knowledge. The meaning of this research is to examine more in the role of the Community Cup Kamisan in building the creative economy in the City of Metro Lampunng

Key Word: Collective intellectual, Community Cups Kamisan, Creative Economy

\section{A. Pendahuluan}

Tantangan kaum intelektual di era globalisasi semakin kompleks. Wacana tentang hegemoni kapitalisme misalnya, semakin mempersulit gerakan sosial dalam melawan tirani korporasi-korporasi besar baik di lapangan politik, ekonomi, media, kebudayaan bahkan pada dunia pendidikan tersendiri. Elit-elit penguasa dan pengusaha semakin kuat menancapkan pengaruhnya sebagai pemilik partai politik, media (televisi, koran, portal online) dan sumber daya alam negara. Konglomerasi media misalnya gencar mempengaruhi publik sesuai kepentingan partai yang dimiliki oleh pemilik media sekaligus. Dari realitas di atas, tercermin seperti yang dikatakan Altschull's dalam studi kepemilikan dan pengawasan media, bahwa,"isi media selalu merefleksikan kepentingan pihak yang membiayai mereka (Mc Quails, 2000 : 193).

Dalam ilmu sosial terutama filsafat dan sosiologi, sering terjadi oposisi diantara subjektivisme dan objektivisme yang sering tidak terdamaikan (Bourdieu, 1992 : 25). Dikotomi antara subjektivisme dan objektivisme tersebut meskipun terlihat bertentangan, namun pendekatan kedua perspektif ini diperlukan untuk menemukan hubungan saling mempengaruhi atau dialektika diantara keduanya. Keduanya saling terkait dan saling mempengaruhi dalam satu proses kompleks untuk menghasilkan praktik sosial (Takwin, 2005 : xvii). Praktik sosial tidak hanya meletakkan subjek pada peran utama pembentukan dunia, melainkan juga memperhitungkan konteks ruang dan waktu yang melatarbelakanginya (Rusdiarti,, 2003 : 33). Maka untuk 
dapat mendialektikakan keduanya, Bourdieu merumuskan konsep habitus, arena, dan modal. Ketiga konsep ini berada dalam satu bingkai yang dinamai Bourdieu dengan strukturalisme genetik (Bourdieu, 2010 : xiii).

Fakta yang terjadi, demokrasi liberal, neoliberalisme ekonomi, budaya asing yang masuk menjajah ke dalam negeri, mencerminkan propaganda imperalisme masih terjadi dengan cara yang lebih canggih. Intelektual yang dilahirkan Perguruan Tinggi pun akhirnya semakin tidak berdaya melawan arogansi kekuasaan di lapangan politik, ekonomi, sosial, ekonomi dan budaya. Sejalan dengan itu, liberalisasi ilmu pengetahuan masif terjadi dan memiliki ciri: Pertama, munculnya paham positivisme sekuler terhadap pengetahuan ilmiah, aktifitas teknologi, peradaban material, hukum, dan etika pragmatik individu. Kedua, ilmu pengetahuan ilmiah dibagi kedalam disilpin ilmu yang spesialis, mendalam, teknis dan terpisah. Ketiga, ilmu pengetahuan, poritif mendeskridit-kan atau mengeliminasi fungsi agama-agama dalam masyarakat ilmiah (Nanji, 2003 :360-361).

Mohammad Hatta menulis, bahwa seorang intelektual seharusnya memiliki tanggung jawab moral di setiap tindakannya (Hatta, 1984 : 3). Daniel Dhakidae mengenai pewacanaan intelektual yaitu, “...titik berat yang diberikan pada produksi wacana, pertikaian wacana, pergantian wacana, dan kembali kepada formasi wacana baru lagi (Daniel, 2003 : xxvii-xxviii). Charles Kurzman dan Lynn Owens memiliki model pendekatan untuk melihat posisi intelektual dalam masyarakat. Tiga pendekatan tersebut berupaya melihat intelektual sebagai kelas dalam masyarakat, yaitu:

Pendekatan pertama, yaitu menempatkan intelektual sebagai kelas pada dirinya sendiri. Pendekatan ini biasa disebut dengan benda-isme yang merujuk pandangan Julien Benda mengenai pertentangan antara kekuasaan dan kebenaran. Menurut Benda, para intelektual yang masuk ke dalam ranah kekuasaan telah melukai semangat mencari kebenaran, sehingga terciptalah apa yang disebut "pengkhianatan intelektual." 
Pendekatan yang kedua, berakar pada pemikiran Antonio Gramsci, yang menempatkan intelektual sebagai bagian dari kekuasaan untuk memperjuangkan kepentingan masyarakat umum.

Pendekatan ketiga, melihat bahwa intelektual secara potensial bukan merupakan bagian dari kelas mana pun (Mutahir, 2011 : 4-7). tetapi, ketiga pendekatan itu menurut Pierre Bourdieu -selanjutnya akan ditulis Bourdieu sajagagal. Bourdieu menulis, "it fails to include the point of view fromhich it speaks and so fails to construct the game as a whole". Tugas terpenting bagi intelektual ialah mempertahankan otonomi yang dimilikinya untuk melawan intervensi ekonomi dan politik. The genuine intellectual is defined by her or his independence from temporal powers, from the interfence of economic, and political authority (Bourdieu, 1992 : 9).

Otonomi intelektual dalam hal ini tidak selalu merujuk pada perdebatan posisi intelektual dalam bidang politik dan ranah ilmiah, melainkan kemerdekaan dalam berkarya dan menyuarakan kepentingan kelompok yang terpinggirkan (Mutahir, 2011 : 9). Gagasan Bourdieu mengenai intelektual itu disebut intelektual kolektif. Gagasan ini muncul seiring didirikannya penerbitan Liber: Reveu europénne des livre dan dokumentasi Raison d' Agir di awal tahun 1999 sebagai bentuk protesterhadap para, wartawan, dan penulis istana sebagai kaki tangan neoliberalisme. Selain kritik terhadap peran intelektual yang mendukung neoliberalisme, Bourdieu melihat intelektual mengalami pilihan yang sulit. Perlawanan itu harus dilakukan karena kekuasaan ekonomi dan politik telah menghancurkan tatanan dunia sosial dan telah mempengaruhi otonomi intelektual (Mutahir, 2011 : 10).

Munculnya Komunitas Cangkir Kamisan di Kota Metro menjadi fenomena menarik. Berawal dari sebuah komunitas diskusi kamisan (malam jumat) yang terdiri dari bermacam latar belakang pegiat. Bincang pikir (Cangkir) sebuah filosofi kultural sebuah diskusi minum kopi dengan santai tapi penuh dengan obrolan serius. Pegiat komunitas ini beragam mulai dari akademisi, jurnalis, penulis, aktivis mahasiswa, pengusaha, wiraswasta, tokoh agama, dan 
warga Metro bergabung di dalamnya. Dalam pandangan Pierre Boudieu tentang intelektual kolektif, komunitas ini menyatukan ragam intelektual membangun habitus gerakan sosial. Dalam umurnya yang hampir 1 tahun komunitas ini melahirkan banyak kegiatan aktivitas dalam membangun semangat multikulturalisme dan gerakan ekonomi kreatif. Dengan semangat tagline "semua orang adalah guru dan semua tempat adalah sekolah,", komunitas ini telah menggerakan banyak stakeholder dengan tujuan menghidupkan kota kreatif di Metro. Komunitas Cangkir Kamisan sampai hari ini telah melahirkan Rumah Bersama sebagai rumah berbagai komunitas di Metro, Portal jurnalisme warga pojoksamber. com, Bank Sampah Cangkir Hijau, Penerbitan buku indie pertama di Metro Sai Wawai Publishing dan Lembaga riset Sai Wawai Institute.

Penelitian ini mengungkap peran intelektual kolektif dalam dalam pemikiran Pierre Bourdieu. Harapan besar penelitian ini berguna bagi perkembangan praktik sosial dalam masyarakat post-modern. Komunitas Cangkir Kamisan berusaha membangkitkan peran para intelektual di Kota Metro yang memang sejak awal aktif menggagas Komunitas Cangkir Kamisan. Meminjam istilah Arnold J. Toynbe yaitu membangun "Creative Minority" usaha komunitas ini membangun kota dengan pemberdayaan masyarakat kota itu sendiri.

Komunitas ilmiah adalah sebuah institusi atau terdiri dari sekumpulan ilmuwan yang telah memilih paradigma ilmu bersama dan memiliki aturan main tertentu. Paradigma keilmuan ini menjadi suatu kerangka teoritis atau cara memandang dan memahami alam yang telah digunakan oleh sekelompok ilmuwan sebagai pandangan dunia. Komunitas ilmiah juga mempunyai kesamaan bahasa, nilai, asumsi, tujuan, norma, dan kepercayaan (Muslih, 2004 : 128129).

Ekonomi Kreatif menurut laporan United Natoins Conference on trade and Development (UNCTAD) yang berjudul Creative Economy Report 2008 yaitu; "Creative industries can be defined as the cycles of creation, production and distribution of goods and services that use creativity and intellectual 
capital as primary inputs. They comprise a set of knowledge-based activities that produce tangible goods and intangible intellectual of artistic services with creative content, economic value and market objectives" (UNCTAD' $2008: 15)$.

Sedangkan UNESCO menggunakan istilah Ekonomi Kratif dan mendefinisikan sebagai,"...those industries that combine the creation, production, commercialization of contents which are intangible and cultural in nature. These contens are typically protected by copyright and they can take the form of goods and services" (Throsby, $2010: 89$ ).

Berikut bagan proses Intelektual Kolektif bekerja dalam pandangan Bourdieu (Bourdieu, 2010 : xiii).

Bagan 1: Intelektual Kolektif

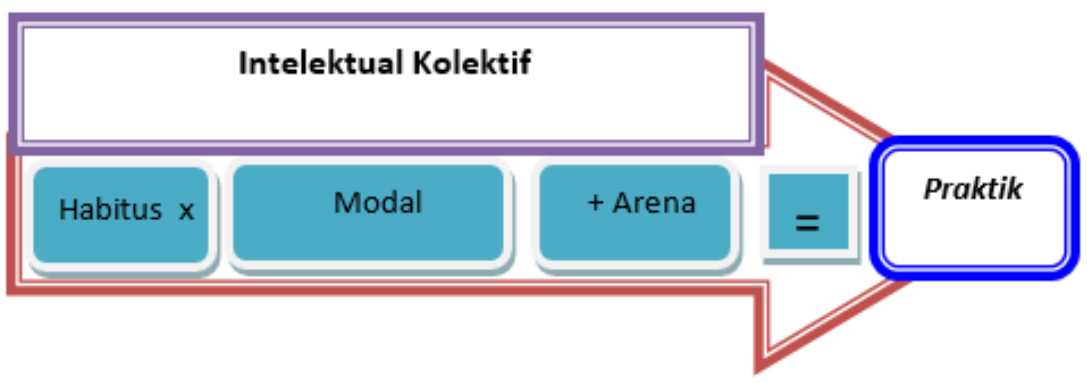

Melihat peran kaum intelektual di berbagai Perguruan Tinggi dalam mempengaruhi praktik sosial dalam teori strukturalisme genetik Bordiaue yaitu habitus, arena dan modal. Dalam hal ini, tulisan ini bermaksud menelusuri peran Komunitas Cangkir Kamisan menjawab tantangan struktur dalam membangun output komunitas yang mampu berkiprah dan survive di masyarakat. Wacana intelektual kolektif menarik untuk diteliti sebagai bagian dari tanggung jawab kaum intelektual dalam hal ini Komunitas Cangkir Kamisan untuk membangun perubahan melalui jalan intelektualisme yaitu pengetahuan. Dengan pengetahuan tersebut komunitas ini selalu mendiskusikan ide-ide baru dan berusaha mengaplikasikan khususnya terkait membangun kemandirian bersama. Untuk itu penelitian ini bermaksud meneliti lebih dalam peran Komunitas Cangkir Kamisan dalam membangun multikulturalisme dan ekonomi kreatif di Kota Metro Lampung. 


\section{B. Komunitas Cangkir Kamisan}

Komunitas Cangkir Kamisan, nama tersebut berasal dari akronim "CangKir" yaitu dari kata 'Bincang' dan 'Pikir'. Secara filosofis, "Cangkir" memiliki makna yaitu sebuah tempat atau wadah yang bisa diisi dengan berbagai macam minuman air-teh, kopi, susu dan lainnya-yang juga dapat mewakili berbagai macam rasa kehidupan. Kemudian Komunitas Cangkir tersebut melakukan diskusi rutin yang bergulir setiap Kamis malam. Diskusi dimulai sejak ba'da isya hingga selesai, dan beberapa pegiat ada yang bertahan hingga dini hari. Setelah berjalan beberapa bulan, komunitas ini kemudian dikenal dengan nama Komunitas Cangkir Kamisan (Wahab, 03 Oktober 2015).

Kemunculan komunitas ini digawangi oleh Oki Hajiansyah Wahab, Rahmatul Ummah dan Dharma Setyawan yang sepakat membangun komunitas epistemik (diskusi pengetahuan yang berkelanjutan). Oki Hajiansyah Wahab adalah anggota AJI (Aliansi Jurnalis Independen) Bandar Lampung sekaligus salah satu pendiri Front Mahasiswa Nasional (FMN), kandidat Doktor di Universitas Diponegoro (UNDIP) yang mengabdikan dirinya sebagai peneliti dan aktifis agraria yang telah mengadvokasi konflik agraria Register 45 Mesuji Lampung sejak tahun 2006. Rahmatul Ummah adalah mantan ketua Komisi Pemilihan Umum (KPU) Metro periode 2009-2014, saat masih menjadi mahasiswa pernah menjadi ketua umum Himpunan Mahasiswa Islam (HMI) cabang Metro dan sekaligus deklarator organisasi Kesatuan Aksi Mahasiswa Muslim Indonesia (KAMMI) di kota Metro (Wahab 03 Oktober 2015).

Sedangkan Dharma Setyawan adalah mantan ketua KAMMI Metro 2009, alumni STAIN Jurai Siwo Metro tersebut melanjutkan S2 di Universitas Gadjah Mada. Kemudian setelah lulus dari Unversitas Gadjah Mada ia memilih karier sebagai akademisi di Sekolah Tinggi Agama Islam (STAIN) Jurai Siwo Metro. Mereka dipertemukan dalam kesatuan ide sebagai kolumnis di media massa lokal Lampungpost. Pertemuan mereka membincangkan banyak 
hal, temasuk kegelisahan akan perkembangan kota dan masa depan minoritas kreatif. "Termasuk mimpi besar membangun peradaban kota, sebuah peradaban alternatif yang kelahirannya dibidani warga kota, mengutamakan partisipasi-kesetaraan dari pada instruksi-hirarkis, menempatkan lebih tinggi 'prestasi' dari pada 'pristise', mendahulukan gagasan dari pada tujuan materi" (Wahab 03 Oktober 2015).

Prinsip yang disebutkan seperti partispasi-kesetaraan diletakkan dalam aplikasi berkomunitas. Misalnya tradisi bantingan atau iuran. Tradisi ini meletakkan pembangunan kemandirian komunitas. Penting akan adanya sebuah tradisi di mana komunitas tidak hanya menggunakan fasilitas dan menengadahkan tangan ke atas. Tapi mulai bertindak bersama secara urunan yang biasa komunitas menyebutnya sebagai 'bantingan' (Wahab 03 Oktober 2015).

\section{Metode}

Tulisan ini menggunakan pendekatan etnografi yang bertujuan untuk memberikan gambaran pengalaman Komunitas Cangkir Kamisan Membangun Ekonomi Kreatif. Data yang digunakan dalam penelitian ini berasal dari data primer hasil observasi lapangan dan wawancara terstruktur dengan informan, sementara data sekunder diperoleh dari data-data yang ada sebelumnya berupa catatan-catatan, koran, dokumen, laporan dan sumber-sumber lain yang berhubungan dengan tema penelitian. Informan penelitian ini adalah para penggiat Komunitas Cangkir Kamisan. Data selanjutnya dianalisis secara induksi-konseptualisasi yang bertolak dari fakta atau informasi empiris (data) untuk membangun kesimpulan.

\section{Membangun Ekonomi Kreatif}

Menurut John Howkins yang dimaksud dengan ekonomi kreatif adalah bisnis ide; bisnis inilah yang mengubah ide menjadi produk ekonomi yang menghasilkan uang (Delee, 2012 : 3). Sedangkan menurut Department of Culture, Media, and Sport (DCMS) United Kingdom (Inggris) mendirikan 
Creative Industries Task Force pada tahun 1997. Kemudian DCMS Creative Industries Task Force (1998) merumuskan definisi sebagai berikut: "Creative Industries as those industries which have their origin in individual creativity, skill and talent, and which have a potential for wealth and job creation through the generation and exploitation of intellectual property and content". Ruang lingkup dari industri kreatif menurut DCMS meliputi, advertising, architecture, the art and antiques market, crafts, design, designer fashion, film, interactive leisure software, music, the performing arts, publishing, software, television and radio.

Ekonomi kreatif merupakan pengembangan konsep berdasarkan modal kreatifitas yang dapat berpotensi meningkatkan pertumbuhan ekonomi. Menurut Presiden Susilo Bambang Yudhoyono (2007) "ekonomi gelombang ke-4 adalah kelanjutan dari ekonomi gelombang ketiga dengan orientasi pada kreativitas, budaya, serta warisan budaya dan lingkungan". Sebelumnya Alvin Tofler dalam bukunya Future Shock (1970) mengungkapkan bahwa “peradaban manusia terdiri dari 3 gelombang; gelombang pertama adalah abad pertanian, gelombang kedua adalah abad industri dan gelombang ketiga adalah abad informasi". Pergeseran dari Era Pertanian ke Era Industrialisasi, disusul dengan era informasi yang disertai dengan banyaknya penemuan baru di bidang teknologi informasi maupun globalisasi ekonomi, telah membawa peradaban baru bagi manusia (Anggraini, 2008 : 144-151).

Ekonomi Kreatif (EK) menurut Diktum Pertama Intruksi Presiden No. 6 Tahun 2009 tentang Pengembangan Ekonomi Kreatif adalah,"Kegiatan ekonomi berdasarkan pada kreativitas, keterampilan, dan bakat individu untuk menciptakan daya kreasi dan daya cipta individu yang bernilai ekonomis dan berpengaruh pada kesejahteraan masyarakat Indonesia.

"Creative industries can be defined as the cycles of creation, production and distribution of goods and services that use creativity and intellectual capital as primary inputs. They comprise a set of knowledge-based activities that produce tangible goods and intangible intellectual of artistic services with creative content, economic value and market objectives" (UNCTAD, 2008 : 15). 
Sedangkan UNESCO menggunakan istilah Ekonomi Kratif dan mendefinisikan sebagai,"...those industries that combine the creation, production, commercialization of contents which are intangible and cultural in nature. These contens are typically protected by copyright and they can take the form of goods and services" (Throsby, $2010: 89$ ).

Berdasarkan pemaparan-pemaparan di atas maka dapat disimpulkan bahwa ekonomi kreatif adalah sebuah kegiatan ekonomi yang didasarkan pada ide-ide kreativitas, keterampilan dan mengandalkan bakat individu sebagai faktor produksi yang utama dalam menciptakan daya kreasi bernilai ekonomis serta mensejahterakan. John Howkins mengidentifikasi sekitar 15 kategori segmen dari ekonomi kreatif termasuk industri bisnis media yang mejadi inti dari industri paten copyright. 15 kategori segmen tersebut antara lain: (1) Periklanan, (2) Arsitektur, (3) Produk Kerajinan, (4) Seni, (5) Disain, (6) Fesyen, (7) Film (termasuk video dan DVD), (8) Musik, (9) Seni Pertunjukkan, (10) Penerbitan Buku, (11) Riset dan Pengembangan, (12) Piranti Lunak/ Software, (13) Mainan dan Game, (14) Video Game, (15) TV dan Radio (Delee, 2012 : 7-8).

Ekonomi kreatif telah menjadi kekuatan baru dalam pembangunan nasional. Jika diruntut sejarahnya, di Eropa industri kreatif dikenal juga sebagai industri budaya, bermula tahun 1944 dipopulerkan di kalangan akademisi melalui kritik Adorno dan Horkheimer The Culture Industry: Enlightenment as Mass Deception (1944). Dari culture industry, ini kemudian berubah menjadi cultural industries. Akhir 1980an Charles Landry menelurkan istilah Kota Kreatif dengan bukunya The Creative City: A Toolkit for Urban Innovators. Kota Kreatif adalah "kota yang menciptakan lingkungan yang mendukung orang untuk memikirkan, merencanakan, dan bertindak dengan imajinasi dalam memanfaatkan kesempatan dan masalah kota".

Richard Florida di The Rise of the Creative Class memaparkan kota kreatif adalah kota yang mampu menanamkan budaya dan memberikan inspirasi 'kreatif' di masyarakat, dan usaha tersebut dapat menunjang upaya 'ekonomi kreatif'. 'Kreatif' itu sendiri merupakan sebuah 
proses, tidak bisa muncul begitu saja secara instan, dan proses kreatif itu sendiri bisa dari cara melihat, cara berfikir, dan cara bertindak.

Metro memilki potensi yang sama, dilihat dari pendapatan daerah yang kecil. Hasil sektor pertanian yang rendah dibandingkan wilayah kabupaten lain. Namun dengan potensi 14 kampus yang ada di dalam kota ini, peran intelektual sangat berpengaruh menerjemahkan ekonomi kreatif ke ranah publik. Dan juga penggunaan teknologi di kota ini mempercepat proses tersebut. Konsep ekonomi kreatif ini adalah dimana ilmu pengetahuan dan tekonologi merupakan input utama dalam mendorong pembangunan ekonomi dan menciptakan pertumbuhan ekonomi yang baik. Ilmu pengetahuan diterjemahkan sebagai buah dari peran kaum intelektual didalamnya.

"Ekonomi kreatif adalah sebuah paradigma yang berkembang dari model pemikiran pra-kapitalis, agriculture (pertanian), ekonomi industri kemudian ekonomi informasi kemudian inilah ekonomi kreatif. Ekonomi kreatif kekuatannya berbasis inovasi dan kreatifitas. Berbagai jenis ekonomi kreatif ada 15 jenis, dan dikota Metro banyak SDM sehingga harapannya ekonomi kreatif di kota ini berkembang apalagi berkenaan dengan industri ekonomi berbasis kreatifitas. pengaruh komunitas Cangkir kamisan dalam ekonomi kreatif di Kota Metro jika dihitung secara matematis dan statistik pengaruhnya memang belum nampak. Tetapi kemudian pemikiran-pemikiran ekonomi kreatif dan menjalin network mulai berkembang (Bambang, 14 Oktober 2015).

Perkembanganekonomi kreatif yang baru dimulai di kota ini (Metro) merupakan upaya membaca potensi kemudian dikemas dengan semangat berkomunitas. Menurut Sutiyo Komunitas cangkir kamisan walaupun baru berumur satu tahun, mereka banyak mendorong perkembangan ekonomi kreatif dengan menggandeng penggiatnya dalam berbagai event. "Sebagai contoh kami dulu tidak mengenal kaos abe, tapi kemudian kami mengenal pas abe di gandeng oleh kawan-kawan komunitas " (Sutiyo, 10 November 2015).

Akademisi yang ada di Komunitas Cangkir Kamisan 
membantu mempermudah stimulus perkembangan industri kreatif. Pertama, Melahirkan portal jurnalisme warga pojoksamber.com adalah langkah awal mengawal perekonomian kreatif. Bergerak dalam jurnalisme warga memudahkan akses warga mengembangkan potensi bisnis atau periklanan yang sudah ataupun belum tumbuh. Kedua, membuat penerbitan dan percetakan indie Sai Wawai Publishing mempertegas sinergitas industri kreatif yang pertama dibentuk. Ketiga, Bank Sampah Cangkir Hijau sebagai perjuangan dalam bidang ekonomi kreatif berbasis lingkungan hidup. Keempat, kemudian melanjutkan pertumbuhan industri kreatif di sektor research (penelitian) dengan mendirikan Sai Wawai Institute dan Kelima, pengembangan Metro Photography, musik dan film dokumenter.

\section{Portal Online Pojoksamber.com}

Industri kreatif yang bergerak dalam sektor periklanan ini adalah portal jurnalisme warga pertama di Lampung. Pertama kali muncul portal ini bukan bertujuan sebagai media komersial, justru sebagai media informasi dan pembelajaran atau lebih mudah disebut portal jurnalisme warga. Seperti yang diungkapkan Rahmat sebagai pimpinan redaksi "Sejak mula, portal ini telah meneguhkan diri sebagai media nonmainstream, media yang hidup dan dihidupkan oleh warga. Kegiatan besarnya, adalah menghidupkan budaya literasi dan memproduksi penulis-penulis baru di kota ini" (Ummah, 12 Oktober 2015).

Pojoksamber.com secara resmi didirikan pada 28 Oktober 2014. Pendirian pojoksamber.com merupakan ide dan kreasi 25 orang inisiator. Masing masing inisiatior swadaya kumpulkan uang masing-masing satu juta rupiah. Dari uang yang terkumpul tersebut menjadi modal awal untuk membuat portal jurnalisme warga pertama di kota Metro bahkan di Lampung. Sejumlah nama pendiri tersebut adalah sebagai berikut; Rahmatul Ummah (Mantan Komisioner KPU Metro), Fritz Ahmad Nuzir (Dosen cum Arsitek), Bambang Suhada (Dekan FE Universitas Muhammadiyah Metro), Dharma Setyawan (Dosen STAIN METRO), Imam Mustafa (Dosen STAIN METRO), Sutiyo (Dosen 
STISIPOL Dharma Wacana Metro), Amri (Dosen STIT Agus Salim Metro), Rio Dermawan (BMT ADZKIYA), Elly Agustina (Bimbel BROTHERHOOD), Oki Hajiansyah Wahab (Peneliti PKKPHAM FH UNILA), HS Tisnanta (Dosen FH UNILA), Rudy, (Dosen FH UNILA), Hertanto (Dosen FISIP UNILA), Hifni Septina Carolina (Guru), Dwilia Delfi (Guru SD), Dyah Widyani (PNS Kota Metro), Endri Y (Jurnalis), Welly Alhendri,SE (Wiraswasta), Achyani Subandi (Dosen FKIP UMM), Erik Pujianto (Mahasiswa, penggiat FOSSEI Filantropi), Abdul Rohman Wahid (Koki), Imroatul Munawaroh (Guru MART), Apri Nuzulis Tiana (Seniman), E.Rudiyanto (Jurnalis), Amrullah Khusain (Dosen STAIN Metro).

Pojoksamber.com sebagai portal jurnalisme warga bertepatan pada hari sumpah pemuda. Hal tersebut juga sebagai bentuk penanda meneguhkan pojoksamber.com hidup dan dihidupi anak-anak muda. Kegiatan ini disambut hangat warga Metro dilihat dari ratusan orang berkumpul di Taman Kota Metro. Dan menghadirkan guru besar dari Kitakuyutshu University Jepang, Prof. Bart Dewancker.

Gambar. 1

Prof. Bart Dewancker, Lukman Hakim Walikota Metro 20102015 dan Anak-Anak SD Muhammadiyah Metro

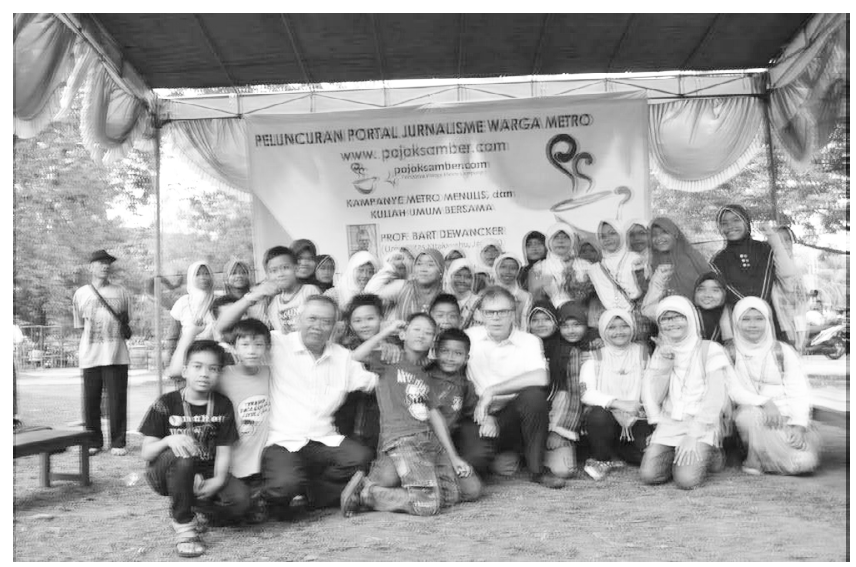

Sumber foto: Koleksi Pribadi (2015) 
Melalui Program Klinik Menulis dan Kampanye Metro Menulis yang rutin digelar setiap bulan, pojoksamber.com terus bergerak mengedukasi warga. Portal berita non-mainstrem (bukan arus utama) ini mencoba mengimbangi hegemoni media mainstream (arus utama). "Jika jurnalis memerlukan masyarakat untuk mendapatkan informasi, untuk kemudian disampaikan kepada publik, kenapa tidak masyarakat sendiri yang menyampaikan informasi itu langsung ke publik" (Ummah, 12 Oktober 2015 ). demikian pernyataan Rahmat yang mengulas alasan kenapa pojoksamber.com penting didirikan. Diambil dari nama sebuah lapangan di Kota Metro, pojoksamber. com merupakan sebuah media cyber berbasis jurnalisme warga. Pojoksamber.commemberikan prioritas terhadap berita-berita seputar Kota Metro. Karena prioritas tersebut, pojoksamber. com mengusung tagline Portalnya Warga Metro.

Keterlibatan warga tidak hanya sebagai penerima informasi. Warga juga dapat berperan sebagai jurnalis, dengan turut aktif menyampaikan informasi, dan pojoksamber. com menjadi wadah informasi seputar Metro, Lampung, Nasional bahkan Internasional. Bahkan beberapa kontributor memanfaatkan jaringan warga Indonesia yang bekerja atau sedang menempuh pendidikan di luar negeri seperti kontributor dari negara Hongkong, Belanda, Jepang, Malaysia, Inggris, Perancis dan lainnya. Untuk memenuhi kualitas berita, informasi yang disampaikan warga tetap disunting oleh tim editor pojoksamber.com secara profesional.

Peneliti mencatat tujuan pojoksamber.com sebagai media informasi warga Kota Metro yaitu mencoba menumbuhkan budaya menulis warga kota Metro, mengoptimalkan potensi dan kreativitas warga Kota Metro, dan menjadi mitra promosi bisnis, jasa, maupun pendidikan bagi warga kota Metro. Untuk mencapai langkah tujuan tersebut pojoksamber.com secara aktif melakukan berbagai kegiatan. Kampanye Metro Menulis dan Metro Melek Media, pelatihan jurnalisme warga, lomba penulisan, hingga diskusi maupun seminar, menjadi kegiatan rutin yang direalisasikan portal jurnalisme warga Pojoksamber. com.

Sebagaimediaedukasiyangdibalutdenganteknologi, dapat 
memberi akses setiap warga untuk melihat perkembangan dan merangsang timbulnya ide-ide kreatif yang terus disebarluaskan melalui portal. Langkah ini senada dengan teori Daniel L. Pinks dengan paparannya tentang kebutuhan yang harus dijawab di era kreativitas yaitu High Tech yang di dalamnya high concept dan high touch (Tim Indonesia, 2008 : 2). High tech, diartikan sebagai kesadaran warga di era kreatifitas bahwa teknologi menjadi penting dalam menumbuhkan ataupun mendiskursuskan ide-ide yang belum nampak sekalipun. Dan apakah mampu menembus ruang empati dalam interaksi interaksi sosial.

\section{Sai Wawai Publishing (penerbitan buku Indie di Kota Metro)}

Metro sebagai kota pendidikan, idealnya melahirkan berbagai karya intelektual sebagai bagian tak terpisahkan dari tradisi visi kota yang diemban. Ketiadaan penerbit lokal Metro membuat karya anak-anak Metro menjadi terhambat. Sai Wawai Publishing hadir untuk melengkapi kehadiran laman pojoksamber.com, yang notabene adalah lamanjurnalisme warga guna mendorong tradisi menulis dan membaca.

Penerbitan bukuSai Wawai Publishing $(S W P)^{1}$, sebuah penerbitan indie yang didekasikan untuk mendukung dan membantu para penulis di Kota Metro. Salah satu Industri kreatif yang bergerak dalam bidang percetakan dan penerbitan. SWP merupakan penerbitan buku pertama kali di Kota Metro. Berdiri sejak 13 November 2014. Memilih bergerak di jalur penerbitan buku self-publishing, pendirian SWP bertujuan membantu penulis-penulis kreatif di Kota Metro, untuk menerbitkan karya mereka tanpa ada batasan.

Rio Dermawan, Direktur SWP menjelaskan tujuan munculnya industri kreatif ini. "untuk menyebarkan dan mengkampanyekan gagasannya lewat buku. Ide dan gagasan tidak boleh berhenti dalam file-file yang dikonsumsi sendiri, oleh karena itu SWP mendorong untuk diterbitkan sehingga bisa menjadi gagasan yang abadi dalam bentuk buku"(Dermawan, 21 Oktober 2015). Dengan begitu kehadiranya menjadi pengerak perubahan kota menuju kota yang warganya terus belajar

1 Sai Wawai artinya Satu Kebaikan, dengan harapan menjadi penerbitan buku yang terus konsisten membangun kebaikan dengan memperjuangkan Metro menulis. 
Gerakan Komunitas Cangkir Kamisan Membangun Ekonomi ...

(learning society).

Sai Wawai Publising menerbitkan buku-buku yang berkualitas adalah tujuan utama, namun jika melihat sumber daya lokal yang ada tujuan di atas masih utopis. Untuk itu Sai Wawai Publising mencoba memberikan sebuah terobosanterobosan baru dan memberikan arahan khusus terhadap penulis tentang pengetahuan kekinian. Penjualan tidak ditargetkan secara khusus dan pemasaran masih berputar ke kalangan lokal.

Sai Wawai Publishing sebagai media partnert mendukung transfer ilmu pengetahuan. Para penggiat Komunitas Cangkir Kamisan juga meyakini bahwa setiap karya tulis memiliki kreativitas yang unik. Tetapi, sistem penerbitan mainstream yang mementingkan oplah (jumlah) penjualan buku, kerap menjadi penghambat karya-karya tulis kreatif, untuk bisa diterbitkan menjadi sebuah buku. Mengamati kondisi tersebut, Sai Wawai Publishing berusaha hadir sebagai sebuah solusi.

Tabel 1.

Daftar Buku di terbitkan oleh SWP

\begin{tabular}{|c|l|l|l|l|}
\hline No & Judul buku & \multicolumn{1}{|c|}{ Penulis } & \multicolumn{1}{c|}{ Tahun } & \multicolumn{1}{c|}{ Foto } \\
\hline 1 & $\begin{array}{l}\text { Membangun } \\
\text { Paradigma } \\
\text { Kemaritiman } \\
\text { Indonesia }\end{array}$ & $\begin{array}{l}\text { Dr.HS. } \\
\text { Tisnanta, et al } \\
\text { (PKKPHAM } \\
\text { Unila) }\end{array}$ & $\begin{array}{l}\text { November } \\
2014\end{array}$ & \\
\hline 2 & $\begin{array}{l}\text { Kabut } \\
\text { Pendidikan } \\
\text { Di Indonesia }\end{array}$ & $\begin{array}{l}\text { Budi Sugandi } \\
\text { (mahasiswa } \\
\text { S2 Marmara } \\
\text { University, } \\
\text { Turkey) }\end{array}$ & $\begin{array}{l}\text { November } \\
2014\end{array}$ & \\
\hline 3 & $\begin{array}{l}\text { Menulis } \\
\text { Asyik }\end{array}$ & $\begin{array}{l}\text { Udo Z Karzi } \\
\text { (Jurnalis cum } \\
\text { Budayawan } \\
\text { Lampung) }\end{array}$ & Desember & \\
\hline
\end{tabular}




\begin{tabular}{|c|c|c|c|c|}
\hline 4 & $\begin{array}{l}\text { Dilema } \\
\text { Kurikulum } \\
\text { Berbasis } \\
\text { Rezim }\end{array}$ & $\begin{array}{l}\text { Pelajar Kota } \\
\text { Metro }\end{array}$ & $\begin{array}{l}\text { Januari } \\
2015\end{array}$ & \\
\hline 5 & $\begin{array}{l}\text { Bagaimana } \\
\text { Mengelola } \\
\text { Pengajaran }\end{array}$ & $\begin{array}{l}\text { Sucipto,M. } \\
\text { Pd.I } \\
\text { (Dosen STIT } \\
\text { Agus Salim) }\end{array}$ & $\begin{array}{l}\text { September } \\
2015\end{array}$ & Ai \\
\hline 6 & $\begin{array}{l}\text { Filsafat } \\
\text { Politik } \\
\text { Kenegaraan } \\
\text { Bung Hatta }\end{array}$ & \begin{tabular}{|l} 
Dr. Mat \\
Jalil,M.Hum
\end{tabular} & 2015 & \\
\hline 7 & \begin{tabular}{|l} 
Gotong \\
Royong \\
Melawan \\
Politik uang
\end{tabular} & $\begin{array}{l}\text { Agus Riyanto } \\
\text { dkk }\end{array}$ & 2015 & \\
\hline 8 & Dan lainnya & & & \\
\hline
\end{tabular}

Sumber: SWP (2015)

\section{Sai Wawai Institute}

Industri Kreatif lainnya lembaga riset yaitu Sai Wawai Institute (SWI), Lembaga Survei dan penelitian ini memiliki taglineforeducation, economic \& publikpolicy. LahirnyaSWI berawal dari kegelisahan pegiat diskusi terhadap minimnya penelitian warga, lembaga penelitian yang meneliti perkembangan budaya warga. Bekerja untuk riset kepentingan publik khususnya pencerdasan warga bukan money oriented (orientasi uang). Kerja pertama lembaga ini saat melakukan Survei jejak pendapat tentang politik uang di pemilu kepala daerah kota Metro. Survei yang bekerja sama dengan KPU kota Metro dengan nilai enam juta rupiah. Survei ini bisa berjalan dengan dibantu oleh Populi Center (www.populicenter.org). yaitu Nico Harjanto sebagai konsultan gratis karena untuk kepentingan pencerdasan publik. "Mana ada lembaga lain yang mau bekerja dengan nilai segitu (enam juta rupiah). Tapi mengapa kami terima, karena ini 
Gerakan Komunitas Cangkir Kamisan Membangun Ekonomi ...

berangkat dari hasil ide diskusi kamisan tentang politik uang (Saputra 22 Oktober 2015)."

Sai Wawai Institute punya visi dan misi menjadi lembaga riset local yang kredibel dan fokus dalam mendorong pendidikan, kebijakan publik dan pembangunan ekonomi lokal

Gambar 2.

Foto Nico Harjanto,Ph.D (Direktur Populi Center)

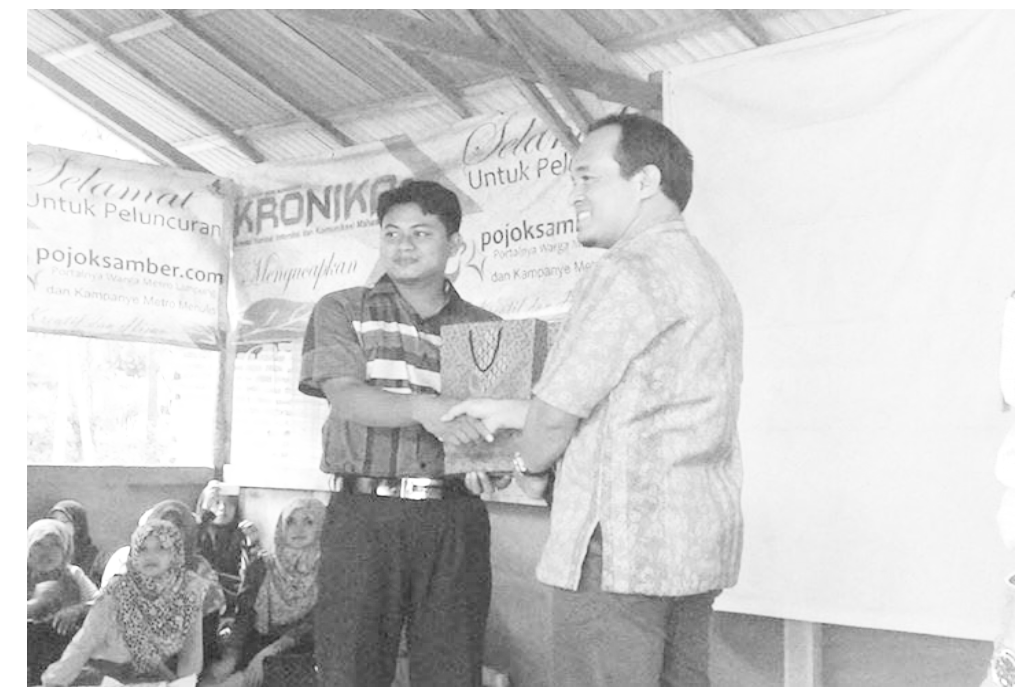

Sumber: SWI (2015)

Tidak hanya bergerak dalam bidang penelitian, bidang kreatif lainya juga menjadi wadah lembaga ini. Sebagai pengakomodir bakat-bakat kreatif pegiat komunitas. Membuat Film dokumenter "Nomor Piro Wani Piro", film yang menarasikan potret politik uang di kota Metro. Film dokumenter ini merupakan kelanjutan hasil survei SWI. Peneliti meninjau lebih dalam, projek film dokumenter tak lain sebagai bentuk multikulturalisme komunitas terhadap penggiat yang memiliki bakat membuat film.

\section{Bank Sampah Cangkir Hijau}

Bank Sampah CangKir Hijau, gerakan ekonomi kreatif ke empat ini adalah respon atas permasalahan sampah di kota Metro. Sampah sebagai masalah klasik warga kota berusaha 
dirubah menjadi berkah. Bergerak dengan penuh keterbatasan, gerakan keempat ini ditapaki dengan penuh optimisme, tidak hanya sebatas menjalankan fungsi sebagai tempat penampungan sampah, pegiatnya juga membangun kesadaran warga melalui pendidikan-pendidikan dan kampanye kepada warga agar terampil memilah sampah, baik organik dan non organik. bank sampah CangKir Hijau adalah jalan mewujudkan mimpi kota hijau yang ramah, warga kota yang sejahtera, dan tak rentan penyakit.

Dari data Kementerian Lingkungan Hidup tahun 2012 tercatat rata-rata setiap orang menghasilkan sampah dua kilogram perhari. Artinya, jika saat ini penduduk Indonesia berjumlah 250 juta jiwa, maka sampah yang akan dihasilkan adalah 500 ton sampah dalam 1 hari. Bayangkan berapa banyak sampah yang terus diproduksi selama sebulan, setahun atau beberapa tahun mendatang jika tidak diimbangi dengan rasa peduli terhadap lingkungan dalam pengelolaan sampah.Melihat permasalahan tersebut itulah inisiatif untuk membuat bank sampah yang berbasis pemberdayaan masyarakat. Seperti yang diungkapkan Lukman Hakim sebagai direktur Bank Sampah (Hakim, 23 Oktober 2015).

"Bank sampah yang didirikan sebagai ikhtiar menjaga kebersihan lingkungan sebagaimana diperintahkan oleh Islam. Islam juga memerintahkan kepada penganutnya untuk senantiasa menjaga keseimbangan alam dan tidak membuat kerusakan di bumi. Fikih pertama juga memerintahkan tentang kebersihan atau ath-Thaharah, artinya manusia memang diperintahkan untuk menjaga kebersihan dan kesucian karena sesuai dengan fitrahnya."

Dalam pengelolaannya, bank sampah melibatkan masyarakat sebagai upaya transformasi nilai dan ilmu pengetahuan sehingga berupaya membangun kesadaran masyarakat atas pentingnya menjaga lingkungan. Keterlibatan masyarakat adalah upaya untuk melakukan proses edukasi secara langsung sehingga apa yang akan disampaikan bisa berjalan secara optimal. Selain masyarakat, juga melibatkan berbagai stake holders untuk mendukung gerakan bank sampah. Keterlibatan multistake holders diantaranya pihak pemerintah, swasta, Baitul mal Wat Tamwil, akademisi, komunitas, dan media. 
Gerakan Komunitas Cangkir Kamisan Membangun Ekonomi ...

Saat launching pertama kali, Bank Sampah dihadiri masyarakat dengan antusias. Terlihat seperti gambar di bawah ini, Walikota Metro Lukman Hakim secara resmi melaunching Bank Sampah pertama yang ada dikota Metro.

\section{Gambar 3.}

Launching Bank Sampah Cangkir Hijau dan Kunjungan warga Perancis berkunjung ke Bank Sampah Cangkir Hijau 2
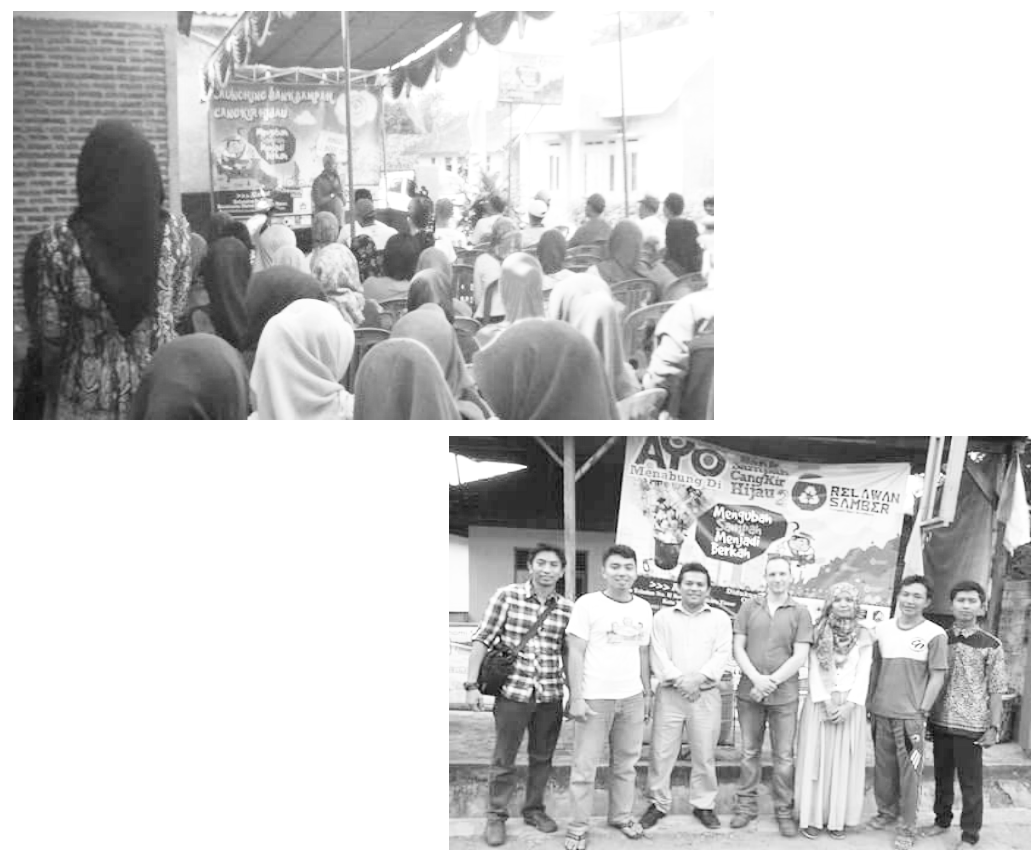

Sumber Foto: Koleksi Foto Rahmatul Ummah (2015)

Dalam dokumentasi yang didapatkan, selain Lukman Hakim (Walikota Metro), beberapa akademisi Metro dan Lampung termasuk sebagai Pembina Bank Sampah Cangkir Hijau. Bambang Suhada dosen di Universitas Muhammadiyah Metro dan M. Akib Dosen Universitas Lampung. Selain itu dr. Wahdi Siradjudin (Direktur Rumah Sakit AMC Metro) juga menjadi pembina sekaligus menyerahkan CSR Rumah Sakit AMC berupa Motor Bank Sampah. dan yang terakhir adalah Chusnunia Chalim (Anggota DPR RI).

Setelah beberapa bulan berjalan, dampak perkembangan Bank Sampah Pertama di Metro ini semakin berkembang dan sempat beberapa kali menjadi lokasi kunjungan dari warga 
asing. Dan sempat Konsultan Kementerian Pekerjaan Umum dan Perumahan Rakyat (Kemen PU-Pera) Indonesia dan Perancis berkunjung ke Bank Sampah Cangkir Hijau (http:// www.pojoksamber.com/berita-foto-konsultan-kementrian-pudari-perancis-kunjungi-bank-sampah-cangkir-hijau/)

\section{Metro Photography, Musik dan Film Dokumenter}

Selain itu Komunitas ini juga mengembangkan Ekonomi Kreatif dalam bentuk Fotography, Musik dan Film Dokumenter Dari pertemuan intensif Kamisan, tiap-tiap komunitas diberi ruang sesuai dengan skill dan hobinya. Mulai dari Musik, komunitas telah meluncurkan mini album yang Launching tanggal 16 agustus. Mini album pertama dan perdana di kota Metro merupakan kolaborasi anak-anak muda Metro. Group Musik tersebut adalah Cangkir akustik, Cangkul Bumi dan KPJ. Album berisi enam lagu dengan genre musik akustik seperti gambar dibawah ini.

Gambar 4.

Kegiatan Lounching Mini Album Titik temu dan pameran metro Photography (Sumber Foto: Dokumen Pribadi (2015)
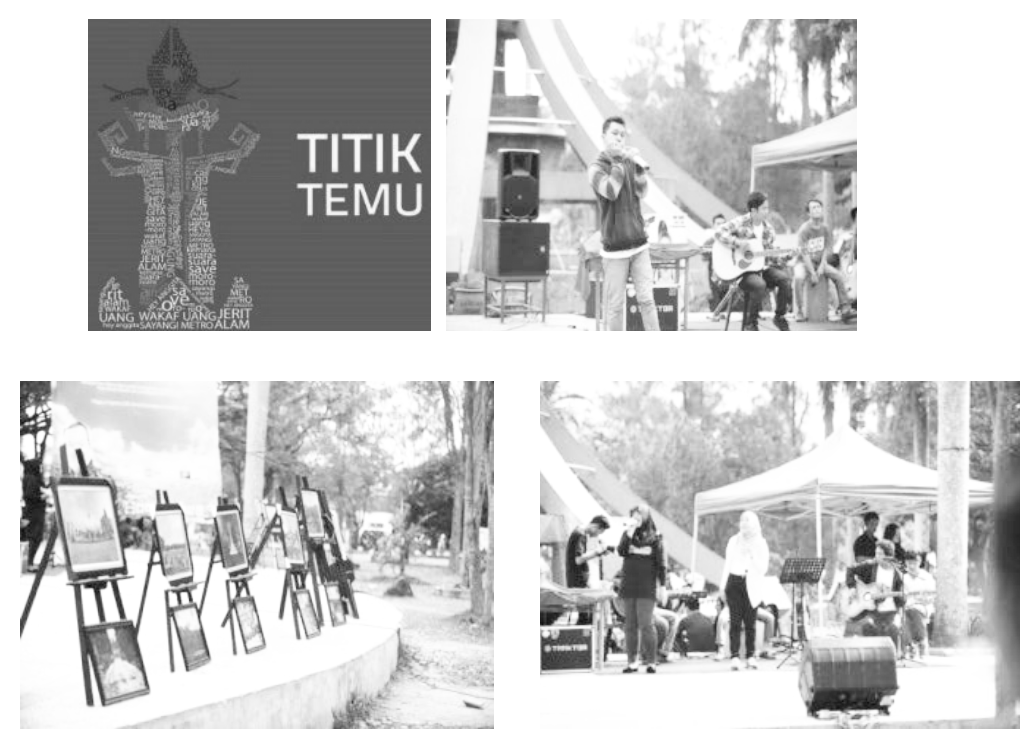

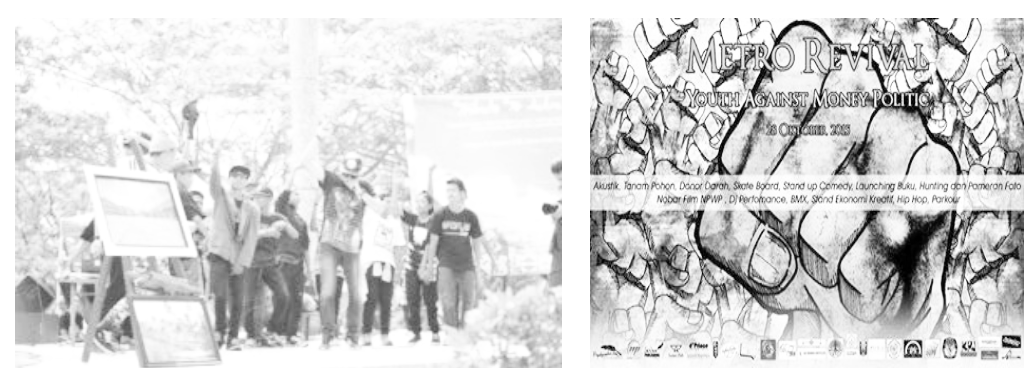

Album ini berisi lagu-lagu sosial, yang pertama lagu \#SayangiMetro lagu yang dibuat untuk sountrack film dokumenter karya komunitas kerjasama dengan Film Dokumenter studi Pelajar Bego (Be Good) SMA N 1 Metro. Lagu Jerit Alam sebagai curahan hati tentang kerusakan lingkungan, Save Moro-Moro lagu persembahan untuk konfik register 45 Moro-Moro. Wakaf Uang yaitu lagu yang dinyanyikan Alfi Boomer dan Agung Hadi Saputra atas permintaan BMT AtTaawun STAIN Jurai Siwo Metro untuk kampanya wakaf uang ke anak-anak muda. Dimana suara-suara Lagu yang kemudian menjadi soundtrack film dokumenter yang dibuat oleh Cangkir Kamisan dan Komisi Pemilihan Umum Metro berjudul "Nomor Piro Wani Piro". Album ini dikerjakan secara swadaya, dan setiap donatur mendapatkan $10 \mathrm{~cd}$ Titik Temu. Album ini diluncurkan bersamaan dalam agenda kolaborasi kegiatan "Tribute To Lukman" sebuah acara untuk memperingati masa akhir bakti Lukman Hakim sebagai wali kota Metro.

Selain musik, Metro Photography (MP) mengadakan pameran foto "Metro dalam Lensa", Komunitas Zenfonegraphy mengadakan lomba foto dengan tema Explore Metro. Serta launching album titik temu. Selain itu beberapa komunitas lainnya terlibat. Pameran foto sketsa dari Komunitas Sketsa, diiringi juga Disk Jockey (DJ) Gaer89, Beat Box, dan kelompok akustik seperti Cakir akustik, Cangkul Bumi, dan KPJ yang semuanya adalah talenta muda lokal kota Metro.

Acara youth Revival merupakan perlawanan terhadap politik uang yang dilakukan komunitas lewat film NPWP (Nomer Piro Wani Piro) yang menyentuh segmen anak muda. Berbagai komunitas anak muda yang terlibat misalnya akustik, skate board, stand up comedy, hunting dan pameran foto, DJ performance, BMX, parkour, Hip Hop, jejak cakrawala alam (JCA), komunitas 
pisang, stand ekonomi kreatif dan masih banyak lagi komunitas kreatif lain.

Gambar 5.

Kegiatan Metro Revival Lampung Post dan Cd Film Lawan Politik Uang
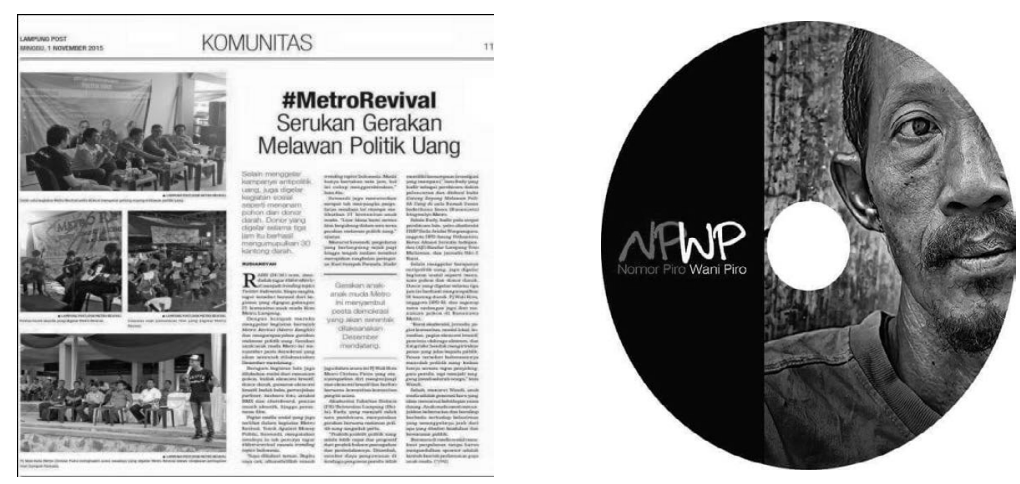

Sumber Gambar: Lampung Post (2015)

\section{E. Kesimpulan}

Intelektual kolektif adalah sikap kesadaran memberdayakan semua potensi dan ragam profesi untuk membangun kerjasama dalam berbagai bidang. Komunitas Cangkir Kamisan di bangun dengan semangat solidaritas, egaliter dan tanggungjawab. Komunitas Cangkir Kamisan rutin berdiskusi setiap Kamis Malam selepas Isya'. Komunitas sejak awal dibangun dengan semangat perbedaan, baik latar belakang organisasi, pandangan ideologi, pekerjaan, suku bahkan agama. Para pegiat memandang multikulturalisme adalah sebuah keniscayaan yang menjadi bagian dari berkembangnya komunitas cangkir, sehingga semua penggiat komunitas mau melepaskan cangkang ego identitas.

Tantangan komunitas diskusi epistemik selain membangun ide adalah mendaratkan ide menuju praktik nyata. Komunitas Cangkir Kamisan dengan semangat Cangkir 'bincang pikir', terus berupaya membangun sikap kolektif dengan berbagai ragam profesi untuk melakukan kerja-kerja komunitas. Selain itu berbagai ragam profesi 
dari dosen, mahasiswa, pelukis, seniman, jurnalis, fotography, dan profesi lainnya. Komunitas ini juga banyak beranggotakan aktifis mahasiswa, mulai dari mahasiswa Universitas Muhammadiyah Metro, STAIN Metro, STIT Agus Salim dan beberapa komunitas kreatif yang mulai tertarik berdiskusi dan membangun kolaborasi gerakan dalam karya ekonomi kreatif.

Penelitian ini mencoba mengupas lebih dalam peran intelektual kolektif Komunitas Cangkir Kamisan dalam upaya membangun multikulturalisme dan ekonomi kreatif. Mereka semakin tercerahkan dengan diskusi dan pelan namun pasti melakukan aksi nyata gerakan-gerakan sosial di tengah masyarakat. Dalam praktiknya Komunitas ini juga mengambangkan multikulturalisme dalam semangat harmoni. Komunitas sejak awal di bangun dengan semangat perbedaan, baik latar belakang organisasi, pandangan ideologi, pekerjaan, suku bahkan agama. Para pegiat memandang multikulturalisme adalah sebuah keniscayaan yang menjadi bagian dari berkembangnya komunitas cangkir sehingga semua pagiat komunitas harus melepaskan identitas yang melekat para masing-masing individu. Dimulai dengan membangun Rumah Bersama yang dibangun dengan semnagat gotong rotong oleh penggiat komunitas tersebut. Selain itu juga melibatkan berbagai pihak dalam mendatangkan material rumah bersama dengan gerakan sedekah material mulai dari papan, kayu, pasir, semen, paku, asbes, bata dan material lainnya. Berbagai piha juga menyumbang mulai dari akademisi, aktifis mahasiswa, komunitas kreatif, tokoh agama, pendeta, romo dan warga lainnya.

Komunitas Cangkir Kamisan juga bergerak berjuang membangun ekonomi kreatif. Pertama, Melahirkan portal jurnalisme warga pojoksamber.com adalah langkah awal mengawal perekonomian kreatif. Bergerak dalam jurnalisme warga memudahkan akses warga mengembangkan potensi bisnis atau periklanan yang sudah ataupun belum tumbuh. Kedua, membuat penerbitan dan percetakan indie Sai Wawai Publishing mempertegas sinergitas industri kreatif yang pertama dibentuk. Ketiga, Bank Sampah 
Cangkir Hijau sebagai perjuangan dalam bidang ekonomi kreatif berbasis lingkungan hidup. Keempat, kemudian melanjutkan pertumbuhan industri kreatif di sektor research (penelitian) dengan mendirikan Sai Wawai Institute dan Kelima, pengembangan Metro Photography, musik dan film dokumenter.

\section{F. Rekomendasi}

Komunitas Cangkir Kamisan adalah sebuah wadah bersama yang terus berkembang melakukan aktifitas sosial. Maka komunitas ini perlu banyak belajar dari komunitaskomunitas lain di luar kota Metro. Komunitas ini pernah belajar dengan Bandung Creatif City Forum (BCCF) dalam hal membangun kreatifitas kota. Maka komunitas ini perlu mengajak semua kalangan berbagai profesi, misal dosendosen di Kota Metro untuk mengajak mahasiswanya terlibat aktif dalam pergerakan kota. Belajar melakukan kerja-kerja sosial, dan berkarya dalam berbagai hal.

Selain itu perlu bagi Komunitas untuk mengajak intelektual-intelektual lainnya untuk membangun gerakan kolektif. Dari sinilah kemudian gerakan dapat menjadikan karyanya sebagai refleksi berpijak dalam berfikir dan bertindak di lapangan sosial. Dan tentu saja masukanmasukan yang berbarti penting dan sangat dibutuhkan Komunitas Cangkir Kamisan sendiri dan terutama bagi bergembangnya pengetahuan dalam gerakan sosial masyarakat. 
Gerakan Komunitas Cangkir Kamisan Membangun Ekonomi ...

\section{DAFTAR PUSTAKA}

Afiff, Faisal, Pilar-Pilar Ekonomi Kreatif, Makalah Rangkaian Kolom Kluster I, BINUS University Jakarta. 2012.

Ali, M. Sayuthi, Metodologi Penelitian Agama; Pendekatan Teori dan Praktek, Jakarta: PT RajaGrafindo Persada, 2002.

Bourdieu, Pierre, Arena Produksi Kultural, Yogyakarta: Kreasi Wacana, 2010.

Bourdieu, Pierre, The Logic of Practice, Stanford: Stanford University Press, 1992.

Delee, Magic Of CreativePreneur (Bagaimana Anda Menjadi Inovatif secara ajaib da nmenjadi seorang bisnis entrepreneur sukses dalam dunia industri ekonomi kreatif), (Jakarta: ABNG Publishing, 2012)

Dhakidae, Daniel, Cendekiawan dan Kekuasaan dalam Negara Orde Baru, Gramedia Pustaka Utama, Jakarta. 2003.

Haryatmoko, Sekolah, Alat Reproduksi Kesenjangan Sosial, dalam Majalah Basis, No. 07-08, Tahun ke-57, 2008.

Hatta, Mohammad, Tanggungjawab Moral Kaum Intelegensia, dalam Mahasin, Aswab \& Ismed Natsir (eds.), 1984,Cendekiawan dan Politik, LP3ES, Jakarta, 1953.

http://www.pojoksamber.com/berita-foto-konsultankementrian-pu-dari-perancis-kunjungi-bank-sampahcangkir-hijau/ , diakses pada 26 Oktober 2015

Jurnal Kajian LEMHANNAS RI, Pengembangan Ekonomi Kreatif guna menciptakan Lapangan Kerja dan Mengentaskan Kemiskinan dalam Rangka Ketahanan Nasional, Edisi 14, Desember 2014.

BISNIS, Vol. 3, No. 2, Desember 2015 
Kautsar R, Maulana,Peran Intelektual Di Tengah Hubungan Negara Dan Masyarakat Dalam Pandangan Pierre Bourdieu: Suatu Telaah Sosiologi Ilmu, Skripsi Penerbit, Yogyakarta : Universitas Gadjah Mada, 2013.

Koentjaraningrat, Metode Wawancara, dalam Koentjaraningrat (ed), Metode Penelitian Masyarakat. cet. II., Jakarta: Gramedia, 1991

Mc Quails, Denis, Mass Communication Theory, London: SAGE Publication, 2000

Muslih, Muh, Filsafat Ilmu: Kajian Atas Asumsi Dasar, Paradigma, dan Kerangka Teori Ilmu Pengetahuan, Belukar, Yogyakarta. 2004,

Mutahir, Arizal, Intelektual Kolektif Pierre Bourdieu, Yogyakarta: Kreasi Wacana, 2011.

Nanji, Azim, Peta Studi Islam: orientalisme dan arah baru kajian Islam barat, Cetakan I, Yogyakarta: Fajar Pustaka Baru, 2003.

Nenny, Anggraini, Industri Kreatif, Jurnal ekonomi Desember 2008 Volume XIII No. 3 hal. 2008

Oki Hajiansyah Wahab 03 Oktober 2015 Pukul 19.30-21.00 WIB (Hasil Wawancara)

Rusdiarti, Suma Riella, "Bahasa, Pertarungan Simbolik dan Kekuasaan", dalam Basis No. 11-12, Th.52, NovemberDesember, 2003.

Takwin, Bagus, Proyek Intelektual Pierre Bourdieu: Melacak Asal-Usul Masyarakat, Melampaui Oposisi Biner dalam Masyarakat, dalam: Harker dkk (ed), (Habitus x Modal) + Ranah = Praktik, Yogyakarta: Jalasutra, 2005. 
Throsby, D, The Economics of Cultural Policy. Cambridge University Press, 2010.

Tim Indonesia Design Power, Rencana Pengembangan Ekonomi Kreatif Indonesia 2009-2015, (Jakarta: Departemen perdagangan, 2008)

UNCTAD. Creative Economy Report 2008. Geneva: UNCTAD, 2008.

Wawancara dengan Bambang Suhada, Dosen Universitas Muhammadiyah Metro pada 14 Oktober 2015

www.populicenter.org

Wawancara dengan Rio Dermawan, 21 Oktober 2015

WawancaraBambangSuhada,DosenUniversitasMuhammadiyah Metro pada 14 Oktober 2015 (Wawancara)

Wawancara Sutiyo, Dosen STISIPOL pada 10 November 2015 (Wawancara)

Wawancara Rahmatul Ummah, 12 Oktober 2015 (Wawancara)

Wawancara Diyan Ahmad Saputra 22 Oktober 2015

Wawancara dengan Lukman Hakim selaku Direktur Bank Sampah Cangkir Hijau , 23 Oktober 2015 